\title{
Communication Skills among Surgical Trainees: Perceptions of Residents in a
}

\section{Teaching Hospital in Northern Nigeria.}

\author{
Abstract
}

\author{
A Ibrahim* \\ ZI Delia* \\ ME Asuku* \\ T Dahiru** \\ Department of Surgery* \\ Department of Community \\ Medicine** \\ Ahmadu Bello University \\ Teaching Hospital Shika \\ Zaria, Nigeria.
}

\author{
All Correspondence: \\ Dr A Ibrahim \\ Department of Surgery \\ Ahmadu Bello University \\ Teaching Hospital Shika Zaria, \\ Nigeria. \\ E-mail: \\ shidoibrahim@yahoo.com
}

\begin{abstract}
Objective
Communication between the surgeon and the patient is a core clinical skill. The ability to communicate with patients and their family members is very important in the optimum care of the surgical patient. Few studies have assessed communication between surgical trainees and their patients in sub-Saharan Africa. In response to this, the communication skills of residents in the department of surgery were evaluated to determine their perception of competency and perceived need for training in communication skills as a basis for developing an effective education programme.
\end{abstract}

\begin{abstract}
Method
A survey of patient care - related communication skills among surgery residents and assessment of competence, rating the importance and perceived need for training in communication skills.
\end{abstract}

\begin{abstract}
Results
Most residents rated their skills as either fairly or extremely competent in all areas except in providing bereavement counseling. They found all skills important and indicated a need for training in them. Senior registrars rated their competence and the importance higher in skills relating to breaking bad news, educating and preparing patients and families for surgery and encouraging them to express their anxieties. $(\mathrm{p}<0.05)$. There was no statistical difference in communication skills between male and female residents $(\mathrm{p}>0.05)$.
\end{abstract}

\section{Conclusion}

Residents face difficult communication challenges with patients and their families. There is a dire need for improved education in communication skills. Understanding the surgical trainees perceptions of patient care related communication skills is the first step in designing an effective education programme.

\section{Key Words: Communication skills, surgical trainees, perception}

\section{Introduction}

$\mathrm{C}$ ommunication between the surgeon and the patient has been described as an important cornerstone of the beautiful art of surgery. ${ }^{1-3}$ It is a core clinical skill which may be complex because it involves interaction between individuals in unequal positions, may be associated with personal and intimate issues of vital importance and could be emotionally laden. ${ }^{4,5}$ Surgeons are required to have good communication skills in the optimum care of their patients. ${ }^{6}$ They have to make sure that patients and their families are adequately informed about their diagnosis, treatment options and possible outcomes. They also have to understand the non verbal cues of patients; the cues of fear, worry, anxiety, guilt or anger. ${ }^{7}$ Surgeons with good communication skills are more likely to obtain accurate clinical data, appropriate informed consent, achieve higher level of patient compliance with surgical and non surgical treatment modalities and build a relationship based on trust. ${ }^{1,4,5}$ Poor patient centered communication has been shown to be a hindrance to surgeonpatient relationship, decreases patient satisfaction and increases litigations. ${ }^{8,9}$

Several studies suggest that surgeons have inadequate communication skills and quite a number of patients are unhappy with the amount of information given to them and the manner of delivery. $2,4,5,8,10$ Indeed very few surgeons have had formal training and most rely predominantly on role modeling and trial and error. ${ }^{1,59}$ In the past decade there has been an increasing recognition of the need to incorporate teaching of communication skills in the curriculum of both undergraduate and postgraduate students in surgery. ${ }^{9,10}$ The postgraduate residency 
training programme in surgery of both the West African College of Surgeons and the National Postgraduate College of Nigeria recognizes that effective care of the patient begins with and must be sustained by good communication skills ${ }^{11-13}$ The Colleges require residents to demonstrate interpersonal and communication skills that will result in effective information exchange with professional associates, patients and their families and ultimately provide quality surgical care. Very few studies have assessed communication between surgery residents and their patients in sub-Saharan Africa. The objective of this study was thus to evaluate the communication skills of residents in the department of surgery, to determine self perception of competency and perceived need for training in communication skills as a basis for developing an effective education program me.

\section{Materials and Method}

Residents in the department of surgery were surveyed after a weekly mortality and morbidity meeting. The questionnaire contained 4 demographic items; age, gender, junior or senior registrar and postgraduate year of training and 10 communication skills items. Appendix a. The communication skills items were adapted from those used by Girgis and Michael. ${ }^{1,10}$ Recommendations were made to the final draft by senior consultants in the department.

The communication skills questions focused on three themes:

(1) perceived level of self competence

(2) the importance of the skill to being a good surgeon and

(3) the need for training residents in these skills. Residents rated perceived level of competence and importance of communication skills on a Likert-type scale of 1 to 4 ("not at all", "fairly", "very", "extremely") and a "yes" or "no" response for a need for training residents in communication skills.

Communication difficulty as a result of language barrier was deliberately not addressed. Completed questionnaires were entered into the Statistical Package for Social sciences (SPSS 17.0 version; SPSS Inc, Chicago Ill). Descriptive frequencies were used to describe resident's perceived competence, importance and need for training in communication skills. Chi square analyses were conducted to identify any significant differences in perceived competence in communication skills among Junior / senior residents and male / female residents.

\section{Results}

Thirty five (35) residents participated in the survey. Twenty nine $29(83 \%)$ were male residents and six 6 (17\%) were female residents. The mean age of the residents was twenty seven 27 years with a range of 25 to 40 years. Most of the residents, seventeen 17 $(48.6 \%)$ were in the second year of residency, followed by 1 st and $3^{\text {rd }}$ year students six $6(17.1 \%)$ each. Twenty four residents $(68.6 \%)$ thought their level of competence was high in educating patient and family and 26 residents $(74.3 \%)$ in preparing patient and family for surgical procedure. The perceived level of competence in the 10 items is presented in Table 1.

The lowest scoring subscales (least competent) were dealing with angry patients and family $26(74.2 \%)$ and providing bereavement counseling $25(71.40 \%)$. 30 or more $(93.8 \%)$ of the residents were of the opinion that communication skills were very important or extremely important to being a good surgeon in the following items; (Table 2) educating patient and their family on diagnosis, preparing patient/ family for surgical procedure, increasing patient/ family ability to remember what they have been told, recognizing when patient/ family are anxious/depressed and providing supportive counseling to patients relatives. When answer rates were compared between senior / junior residents there was a statistical difference. Senior residents were more competent than junior residents in preparing patient and family for surgical procedure $p$ $<0.05$. There was however no statistical difference in communication skills between male and female residents $p>0.05$. (Table 3.) All residents agreed on a need for training surgeons in communication skills.

\section{Discussion}

In this study, residents perceived level of self competence in communication skills was high in all subscales except in dealing with angry patients and their family and providing bereavement counseling. Given that these subscales are associated with expression of pain, emotion and anxiety in the "high pressure" clinical environment of the accident and emergency, intensive care unit and the operating room, the poor ratings of the residents is not surprising. ${ }^{4}$ Critical to these perceived deficiencies are issues of inadequate formal training. ${ }^{7}$ Lesley and Valerie argue that despite the fact that virtually all surgeons at some stage are required to be bearers of sad, bad and difficult news, a woeful lack of training existed. This gap in medical education is bad for the patients, their family and surgeon. ${ }^{2-6}$ Talking about 
Table 1: Resident Perceived Levels of Competence in Communication Skills.

\begin{tabular}{|c|c|c|c|c|}
\hline $\begin{array}{l}\text { Communication } \\
\text { skills }\end{array}$ & $\begin{array}{l}\text { Not } \\
\text { competent } \\
\text { (N) \% } \\
\end{array}$ & $\begin{array}{l}\text { Fairly } \\
\text { competent } \\
\text { (N) \% } \\
\end{array}$ & $\begin{array}{l}\text { Very } \\
\text { competent } \\
\text { (N) \% }\end{array}$ & $\begin{array}{l}\text { Extremely } \\
\text { competent } \\
\text { (N) } \% \\
\end{array}$ \\
\hline $\begin{array}{l}\text { 1. Educating patient } \\
\text { family about } \\
\text { patient's diagnosis } \\
\text { and treatment. }\end{array}$ & (0) 0 & (11) 31.4 & (21)60.0 & (3) 8.6 \\
\hline $\begin{array}{l}\text { 2. Increasing } \\
\text { patients / family's } \\
\text { ability to remember } \\
\text { what they have been } \\
\text { told. }\end{array}$ & ( 1) 2.9 & (20)57.1 & (13)37.1 & (1) 2.9 \\
\hline $\begin{array}{l}\text { 3. Preparing patient } \\
\text { / family for patient's } \\
\text { surgical procedure. }\end{array}$ & (0) 0 & (9)25.7 & (22)62.9 & (4) 11.4 \\
\hline $\begin{array}{l}\text { 4. Recognizing } \\
\text { when patient / } \\
\text { family are anxious } \\
\text { or depressed. }\end{array}$ & (1) 2.9 & (12)34.3 & (15) 42.9 & (7) 20.0 \\
\hline $\begin{array}{l}5 . \text { Encouraging } \\
\text { patient / family to } \\
\text { express anxieties } \\
\text { about patient's } \\
\text { condition. }\end{array}$ & (5) 14.3 & (20)57.1 & (9) 25.7 & (1) 2.9 \\
\hline $\begin{array}{l}\text { 6. Listening to } \\
\text { patients / family } \\
\text { anxieties about } \\
\text { patient's condition. }\end{array}$ & $(0) 0$ & (11)31.4 & $(20) 57.1$ & (4) 11.4 \\
\hline $\begin{array}{l}\text { 7. Dealing with } \\
\text { angry patient / } \\
\text { family. }\end{array}$ & (6)17.1 & (20) 57.1 & (7) 20.0 & (1) 2.9 \\
\hline $\begin{array}{l}\text { 8. Providing } \\
\text { supportive } \\
\text { counseling to patient } \\
\text { / family. }\end{array}$ & (2)5.9 & (16)47.1 & (13)38.2 & (3) 8.8 \\
\hline $\begin{array}{l}\text { 9. Breaking bad } \\
\text { news to patient / } \\
\text { family about } \\
\text { patient's diagnosis / } \\
\text { prognosis. }\end{array}$ & (7)20.0 & (17)48.6 & (8)22.9 & (3) 8.6 \\
\hline $\begin{array}{l}\text { 10. Providing } \\
\text { bereavement } \\
\text { counseling to } \\
\text { deceased patient's } \\
\text { family. }\end{array}$ & (11)31.4 & (14) 40.0 & (8) 22.9 & (2) 5.7 \\
\hline
\end{tabular}

Distressing subjects is unpleasant and the responsibility for giving sad and difficult news should come early during the training of residents as there is little evidence that these difficulties get easier as surgeons become more experienced. ${ }^{7}$ There is evidence that many doctors are aware of their deficits in communication skills. Roche et al in a survey of hospital interns revealed that while $64 \%$ felt competent about their technical skills, only $35 \%$ were competent in communication skills such as preparing patients for threatening procedure ${ }^{1,13 .}$ In another study in Australia surgeons identified significant communication problems. For example $30 \%$ perceived themselves as not being competent at encouraging patients to express anxieties about their condition and $60 \%$ felt they did not have the skills to provide bereavement
Table 2: Importance of Communication Skills to being a good Surgeon.

\begin{tabular}{|c|c|c|c|c|}
\hline $\begin{array}{l}\text { Communication } \\
\text { skill }\end{array}$ & $\begin{array}{l}\text { Not } \\
\text { import } \\
\text { ant } \\
\text { (N) } \% \\
\end{array}$ & $\begin{array}{l}\text { Fairly } \\
\text { importa } \\
\text { nt } \\
\text { (N) } \% \\
\end{array}$ & $\begin{array}{l}\text { Very } \\
\text { importan } \\
\text { t } \\
\text { (N) } \% \\
\end{array}$ & $\begin{array}{l}\text { Extremely } \\
\text { important } \\
\text { (N) } \%\end{array}$ \\
\hline $\begin{array}{l}\text { 1. Educating } \\
\text { patient family } \\
\text { about patient's } \\
\text { diagnosis and } \\
\text { treatment. } \\
\text { 2. Increasing } \\
\text { patients / family's } \\
\text { ability to } \\
\text { remember what } \\
\text { they have been } \\
\text { told. }\end{array}$ & $(0) 0$ & (1)3.0 & (11) 33.3 & (22)66.7 \\
\hline $\begin{array}{l}\text { 3. Preparing } \\
\text { patient / family } \\
\text { for patient's } \\
\text { surgical } \\
\text { procedure. } \\
\text { 4. Recognizing } \\
\text { when patient / } \\
\text { family are } \\
\text { anxious or } \\
\text { depressed. }\end{array}$ & $(0) 0$ & (1) 3.0 & (7) 21.2 & (26)78.8 \\
\hline $\begin{array}{l}\text { 5. Encouraging } \\
\text { patient / family to } \\
\text { express anxieties } \\
\text { about patient's } \\
\text { condition. }\end{array}$ & (2) 6.1 & (4) 12.1 & (16)48.5 & (11)33.3 \\
\hline $\begin{array}{l}\text { 6. Listening to } \\
\text { patients / family } \\
\text { anxieties about } \\
\text { patient's } \\
\text { condition. }\end{array}$ & $(0) 0$ & (5) 15.2 & (10)3 0.3 & (18)54.5 \\
\hline $\begin{array}{l}\text { 7. Dealing with } \\
\text { angry patient / } \\
\text { family. }\end{array}$ & (1)3.0 & (4) 12.1 & $(15) 45.5$ & (13)39.4 \\
\hline $\begin{array}{l}\text { 8. Providing } \\
\text { supportive } \\
\text { counseling to } \\
\text { patient / family. }\end{array}$ & $(0) 0$ & (2) 6.3 & (15)46.9 & (15)46.9 \\
\hline $\begin{array}{l}\text { 9. Breaking bad } \\
\text { news to patient / } \\
\text { family ab out } \\
\text { patient's } \\
\text { diagnosis / } \\
\text { prognosis. }\end{array}$ & (1)3.0 & (3) 9.1 & (8) 24.2 & (21)63.6 \\
\hline $\begin{array}{l}\text { 10. Providing } \\
\text { bereavement } \\
\text { counseling to } \\
\text { deceased } \\
\text { patient's family. }\end{array}$ & (2) 6.3 & (2) 6.3 & (15)46.9 & (13)40.6 \\
\hline
\end{tabular}

counseling to patient's families. ${ }^{1,14}$

The communication skills subscales that were considered most important to being a good surgeon include those that had to do with patient and family education on diagnosis and preparing patient for surgery. These definitely constitute a substantial proportion of surgical consultation time, ${ }^{1}$ thus the perceived high importance to being a good surgeon by residents appears to be consistent with these realities. 
Table 3: Relationship between Level of Residency and Gender in Perceived Competence in Communication Skills

\begin{tabular}{lllllll}
\hline $\begin{array}{l}\text { Communication } \\
\text { skill }\end{array}$ & Junior & Senior & P value* & Male & Female & Pvalue* $^{*}$ \\
& Residents & Resident & & Residents & $\begin{array}{l}\text { Residents } \\
\text { (N) \%. }\end{array}$ \\
& (N) \%. & (N) \% & & (N) \%. & (N)
\end{tabular}

1. Educating patient family about patient's diagnosis and

treatment.

2. Increasing patients / family's ability to remember what they have been told.

3. Preparing patient / family for patient's surgical procedure. 4. Recognizing when patient / family are an xious or depressed. 5. Encouraging patient / family to express an xieties about patient's condition. 6. Listen in $g$ to patients / family anxieties ab out patient's condition.

7. Dealing with angry patient / family.

\section{Providing} supportive counseling to patient / family.

9. Breaking bad news to patient / family ab out patient's diagn osis / prognosis. 10. Providing bereavement counseling to deceased patient's family.
(21)67.8

(13)4 1.9

$(22) 71.0$

$(18) 58.1$

(27) 87.1

(21)67.7

(5) 16.1

$(14) 46.7$

(9) 29.0

(8)25.8

(3) 75.0

$\mathrm{p}=0.730$
$\mathrm{X}^{2}=0.616$

$(21) 72.4$

(3) 50.3

$\mathrm{p}=0.332$

(1) $25 \quad \mathrm{p}=0.876$

$\mathrm{p}=0.876$
$\mathrm{X}^{2}=0.689$

(11)37.9

(3) 50

$\mathrm{X}^{2}=2.207$

(4) 95

$\mathrm{p}=0.028^{*}$
$\mathrm{X}^{2}=7.159$

(21)72.4

(5) 83.3

(18) 62.1

$\mathrm{p}=0.031^{*}$
$\mathrm{X}^{2}=8.844$

(1) $25.0 \mathrm{p}=0.025^{*}$

$\mathrm{X}^{2}=9.315$

(10)34.4

(4) 66.7

$\mathrm{p}=0.849$
$\mathrm{X}^{2}=0.802$

(4) 100

$\mathrm{p}=0.661$

(3) $75 \quad \begin{aligned} & \mathrm{p}=0.661 \\ & \mathrm{X}^{2}=0.828\end{aligned}$

(21) 72.4

(4) 50.0

$\mathrm{p}=0.430$
$\mathrm{X}^{2}=1.687$

75 (3) $\quad \begin{aligned} & \mathrm{p}=0.021^{*} \\ & \mathrm{x}^{2}=11.50\end{aligned}$

(8) 27.5

(0) 0

$\mathrm{p}=0.604$

$\mathrm{X}^{2}=2.732$

(2) 50

$\mathrm{p}=0.184$
$\mathrm{x}^{2}=4.838$

(13) 46.4

(3) 50

$\mathrm{p}=0.10$

$\mathrm{x}^{2}=11.31$

(10)34.4

(2) 50

$\mathrm{p}=0.014^{*}$
$\mathrm{x}^{2}=10.648$

(2) 50

$\mathrm{p}=0.353$

$\mathrm{x}^{2}=3.262$

(8)27.6

(2) 33.2

(1) 16.7

$\mathrm{p}=0.708$
$\mathrm{x}^{2}=1.389$

$\mathrm{p}=0.837$

$\mathrm{X}^{2}=0.850$

$\mathrm{P}$ value* significant $\mathrm{p}$ value at $\mathrm{P}<0.05$
This is remarkable because currently there is little or no formal instruction on communication skills. There is a general tendency for trainees to concentrate almost exclusively in learning surgical skills and pay little or no attention to the communication skills needed in the care of the surgical patient.

It is thus important to emphasize to residents that surgical skills make up one component of a host of skills required to be a good surgeon. Support for training in interactional and communication skills is in line with the research findings in a study in the United States of America where $75 \%$ of surgeons surveyed thought it was very important to include communication skills in training in the undergraduate curriculum. ${ }^{1,15}$ The analysis of perceived level of competence and rating of importance of communication skills item by gender were statistically insignificant. $\mathrm{p}<0.05$. This finding is similar to that of Horwitz et al ${ }^{6}$ who suggest that this is a reflection of a strong homogeneity in personal characteristics among residents in surgery which transcends gender. They propose that this similarity may be the result of a long self-sorting process that begins early in medical school for those who seek a career in surgery and increasingly, have or develop similar characteristics as grouping occurs through both medical school and the surgery residency programme ${ }^{6}$ The influence of level of residency on perceived competency in the communication skills item revealed that senior residents were more competent than junior residents in preparing patient and family for surgical procedure $\mathrm{p}<0.05$. Unlike technical skills that are 
taught in the operating theatre and the surgical skills laboratory, during specified teaching sessions, communication skills are demanded of the resident daily. ${ }^{7.9}$ It is therefore possible that more years of experience in residency may have provided the " practice" necessary for the observed competence in preparing patient and their family for surgical procedures among senior residents.

Residents communicate daily with patients. In the surgery ward when inserting a urethral catheter or in the emergency room when suturing a laceration, the technical component of the procedure is usually associated with an interpersonal and communication challenge. ${ }^{9}$ Thus separating surgical skills from communication skills may send an erroneous message to trainees that surgical skills are of higher value than communication skills. On the contrary, these skills should be integrated and taught before the resident is exposed to the potential negative learning experiences through trial and error or role modeling. ${ }^{2,47}$ Residency programme coordinators should take a more proactive approach in the teaching of communication skills. ${ }^{9} \quad$ Newer techniques in training that emphasize problem solving with incorporation of practice and feedback are thought to be the most effective teaching method in improving communication skills. ${ }^{1,16}$ It has also been stressed that training should be sustained at the postgraduate level since there is evidence that many skills remain fixed at an unsatisfactory level after graduation unless remedial action occurs. ${ }^{1,2}$ One of the most successful methods according to a systematic review by Fellowes et al, seems to be the learner centered approach similar to those pioneered by lipkin in the U.S.A. The essential components are provision of a cognitive component or evidence base for the suggested skills, a behavioral component which allows participants to rehearse the actual communication skills required and a feedback component permitting participants to discuss difficult issues ${ }^{7,17}$ A modification of the Lipkin model was was used during an intensive training course to improve the communication skills of oncologist. The course significantly altered the attitudes and beliefs about the importance of communicating well, and the improvement in skills was still evident a year later when it was assessed. ${ }^{17,18}$ The small sample size may limit interpretations thus a multicentre study should be encouraged as the results of such a study can be used to guide the selection of communication skills items suitable for formal training in the curriculum of the postgraduate colleges of surgery. Another limitation of this study is that the survey measured residents perceptions of self competence (a self report survey) and comfort levels maybe biased and do not necessarily equate with true levels of competence.

\section{Conclusion}

Training residents how to communicate effectively will produce more professionally rewarding consultations but this should be based on excellent educational principles informed by evidence and assessed regularly. We hope our results can contribute to the call for improvements in communication skills training among surgery residents.

\section{Acknowledgement}

The authors thank all the consultants in the Department of surgery Ahmadu Bello University Teaching Hospital Shika Zaria, who contributed to the final draft of the questionnaire and all residents who participated in the study. We are grateful to Dr E.S. Garba, Associate Professor of surgery, Department of Surgery for his valuable contributions to the manuscript. We are also grateful to Mrs. J.O Odengle, Lecturer Department of Mathematics Ahmadu Bello University Zaria for her wonderful corrections and guidance in the statistical analysis of the manuscript.

\section{References}

1 Afaf G, Rob SF, Raoul AW. Preventive and other interactional skills of general practioners, surgeons and physicians: Perceived competence and endorsement of postgraduate training. Prev Med 2001;32:78 -81.

2 Doherty EO, Boyle CA, Shannon W, McGee H, Bury G. Communi-cation skills training in undergraduate medicine. Ir Med J 1990;83, 54-6.

3 Perkins JJ, Sanson-Fisher RW. Increased focus on the teaching of interactional skills to medical practitioners .Adv Health Sci Educ 1996;1:17-28.

4. Ong LML, De Haes CJM, Hoos AM, Lamnes FB. Doctor patient communication; A review of the Literature. Soc. Sci. Med. 1995; 40 (7), 903-918.

5. Fallowfield L, Jenkins V, Saul J, Duffy A. Efficacy of a cancer research UK communication skills training model for oncologists: A randomized clinical trial. Lancet 2002; 359:650 56. 
6. Horwitz IB, Horwitz SK, Brandt ML, Brunicardi FC, Scvott BG. Assessment of communication Skills of surgical residents using the social skills Inventory. Am J Surg 2007; 194:401- 405.

7. Moulton C, Tabak D, Kneebone R, Nestel D, Macrae H, Leblanc VR. Teaching Communication Skills using the integrated procedural performance interest (IPPI): A randomized controlled trial. Am J Surg 2009; 197: 113-118.

8. Yudkowsky R, Algeidi A, Cintron J. Beyond fulfilling the core competencies: An objective structured clinical examination to assess communication and interpersonal skills in a surgical residency. Curr surg 2004; 61:499-503.

9. Fallowfield 1, Jenkins V. Communicating sad, bad and difficult news in medicine. Lancet 2004; 363:312-319.

10.Sise MJ, Sise CB, Sack DI, Goerhing M. Surgeons' attitudes about communicating with patients and their families. Curr surg 2006; 63:213-218.

11 Roche AM, Sanson-Fisher RW, Cockburn J. Training experiences immediately after medical school. Med Educ 1997; 31: 9-16.
$12 \mathrm{http} / / /$ www.wasc-coac.org. Assessed $8^{\text {th }}$ June 2010.

$13 \mathrm{http} / / /$ www.npmon.edu.ng. Assessed $8^{\text {th }}$ June 2010.

14 Girgis A, Sanson-Fisher RW, McCarthy WH. Communicating with patients: surgeons' perceptions of their skills and need for training. Aust NZ J Surgery 1997; 67:775-80.

15. Finocchio LJ, Bailiff PJ, Grant RW, O'Neil EH. Professional com-petencies in the changing healthcare system: physicians' views on the importance and adequacy of formal training in medical school. Acad Med 1995; 70: 1023 -1028.

16 Perkins JJ, Sanson-Fisher RW. Increased focus on the teaching of interactional skills to medical practitioners .Adv Health Sci Educ 1996; 1: 1728.

17 Fallowfield L, Jenkins V, Farewell V, Saul J, Duffy A, Eves R. Efficacy of a Cancer Research UK communication skills training model for oncologists: a randomized controlled trial. Lancet 2002; 359:650-656.

18 Jenkins V, Fallowfield L. Can communication skills training alter physicians' beliefs and behavior in clinics? J Clin Oncol 2002; 20 :76569. 